\title{
The use of genetically modified Roundup Ready soyabean meal and genetically modified MON 810 maize in broiler chicken diets. Part 2. Functional status of the small intestine
}

\author{
J. Czerwiński', M. Słupecka-Ziemilska, J. Woliński, M. Barszcz, P. Konieczka and S. Smulikowska \\ The Kielanowski Institute of Animal Physiology and Nutrition, Polish Academy of Sciences \\ Instytucka 3, 05-110 Jabłonna, Poland
}

KEY WORDS: GM soyabean meal, GM maize, small intestine morphology, apoptosis, mitosis, DNA damage
Received: 23 January 2015

Revised: 28 May 2015

Accepted: 15 June 2015
${ }^{1}$ Corresponding author: e-mail: j.czerwinski@ifzz.pl

\begin{abstract}
The effects of genetically modified (GM) soyabean meal (SBM) and GM maize on the functional status of the small intestine of broiler chickens was studied. Eight diets were prepared, based on conventional or GM SBM (GTS 40-3-2) combined with non-modified maize cvs. Clarica and PR39 F58 or their isogenic GM (MON 810) counterparts cvs. Bacilla or PR39 F56. Diets were fed in mash form from days 1 to 30 of age to 192 Ross 308 broiler females, assigned to 8 groups and kept in individual cages from day 8 of life. The functional status of the small intestine was studied in 8 birds per group after slaughter. The investigation included morphological evaluation of jejunum and ileum sections, calculation of apoptotic and mitotic indices, and measurement of DNA damage in jejunal epithelial cells. There were no statistically significant differences in morphological parameters of the jejunum and ileum except the width of the tunica mucosa in the jejunum, which was greater in birds fed GM than in those given conventional maize. GM SBM had no effect on the apoptotic and mitotic indices in the crypt area or in villi tips, while GM maize did not affect these indices in the crypt area, but increased the apoptotic index in the villi tips of the jejunum. Neither substituting conventional SBM by GM SBM, nor conventional maize by GM maize induced significant DNA damage in the epithelial cells of the jejunum. Our results indicate that the functional development and maturation of the small intestinal epithelium is not greatly modified by the use of GM SBM and GM maize in broiler diets.
\end{abstract}

\section{Introduction}

Over the last few years, interest in food safety and the safety of animal production has been growing within the European Union. Solvent-extracted soyabean meal (SBM) GTS 40-3-2 and MON 810 maize are the most widely used GM crops in animal feeds within the EU (ISAAA, 2014). Even though many studies indicate the lack of adverse effects of first-generation GM SBM and GM maize on animal health (Flachowsky, 2013), the use of GM plants as feed for farm animals is still a subject of public discussion.

According to EFSA (2011), food and feed derived from genetically modified plants and intended to be placed on the EU market should not be nutritionally disadvantageous to humans and animals. It has been proven that transgenic DNA and newly expressed proteins are degraded during the digestion process similarly as native plant DNA and protein, 
and are not transferred to broiler tissues (Świątkiewicz et al., 2010; Einspanier, 2013). In the first part of our study, we demonstrated that the use of GM soyabean meal GTS40-3-2 and/or GM maize MON810 did not negatively affect feed efficiency or the blood lymphocyte subpopulations of birds (Czerwiński et al., 2015). Many reports have shown that GM maize and GM SBM had no effect on the morphology of the small intestine in domestic animals $(\mathrm{Bu}-$ zoianu et al. 2012; Reichert et al. 2012; Walsh et al. 2012) and rats (Kiliç and Akay 2008). However, in vitro studies have demonstrated that glyphosate may provoke cytotoxic effects on cultured human keratinocytes, modifying their antioxidant capacities and impairing morphological and functional cell characteristics, or may induce epidermal cell death (Heu et al., 2012a,b). It may also induce necrosis and apoptosis in mature rat testicular cells (Clair et al., 2012) or may affect the spontaneous motor activity of rat jejunum strips (Chłopecka et al., 2014). Intestinal morphology may be used as an indicator of gut health (Zhang et al. 2014).

The aim of this study was to evaluate whether feeding Roundup Ready ${ }^{\mathrm{TM}}$ soyabean meal and MON810 maize can influence the morphology and functional status of the small intestine in broilers.

\section{Material and methods}

\section{Experimental animals and diets}

The materials used, the composition of the diets, and the experimental procedures were described in detail in the first part of this study (Czerwiński et al., 2015). All procedures were approved by the Local Animal Care and Use Committee. Briefly, 192 one-day-old Ross 308 broiler females were randomly assigned to 8 experimental treatments, 24 birds each, kept in a brooder battery and fed experimental diets ad libitum in mash form. On day 8 , the broilers were weighed and 18 birds per group were allocated to individual cages. Each bird was considered a replication. Birds were fed experimental diets from day one to slaughter, performance was measured between days 8 and 28. Eight experimental diets were formulated to meet or exceed the requirements for broilers (NRC, 1994). The major components of the diets were: conventional or GM soyabean meal (GTS 403-2 Roundup Ready) combined with 2 cultivars of conventional maize (Clarica and PR39 F58) or their MON810 counterparts (cvs. Bacilla and PR39 F56), respectively. Eight birds per group (total 64) with body weights close to group average were used for the investigations described in the present study.

\section{Sampling procedures and fixation}

On day 30, eight chickens per group were killed by cervical dislocation. The abdomen was opened, and three segments of the small intestine were excised (two from the jejunum and one from the ileum). A $10 \mathrm{~cm}$ long segment from the jejunum (starting $11 \mathrm{~cm}$ anterior to Meckel's diverticulum) was washed with $\mathrm{NaCl}$ solution $(0.9 \% \mathrm{w} / \mathrm{v})$ to remove digesta and kept on ice in solution A ( $96 \mathrm{mM} \mathrm{NaCl}, 27 \mathrm{mM}$ Na-citrate, $1.5 \mathrm{mM} \mathrm{KCl}, 0.8 \mathrm{mM} \mathrm{KH}_{2} \mathrm{PO}_{4}, 5.6 \mathrm{mM}$ $\mathrm{Na}_{2} \mathrm{HPO}_{4}, 25 \mathrm{mM} \mathrm{NaHCO}, 1 \mathrm{mM}$ dithiothreitol, $2.5 \mathrm{mM}$ L-glutamine, gassed with $95 \% \mathrm{O}_{2}-5 \% \mathrm{CO}_{2}$ ) for evaluation of DNA damage by comet assay.

Two $3 \mathrm{~cm}$ long segments excised from the jejunum (starting $6 \mathrm{~cm}$ anterior to Meckel's diverticulum) and ileum (starting $15 \mathrm{~cm}$ anterior to the ileo-caecal junction) were washed with $10 \%$ formaldehyde in phosphate-buffered saline (PBS) to remove digesta, then fixed in the same solution for one day, dehydrated, saturated with xylene and embedded in paraffin. The paraffin-embedded samples were cut into $4.5 \mu \mathrm{m}$ sections with the use of a microtome (Zeiss, Germany) and mounted on silanetreated glass slides. Prior to staining for histology and evaluation of apoptosis and mitosis, the sections were dewaxed in xylene, rehydrated in decreasing grades of ethanol, and washed in PBS buffer.

\section{Histology}

For histological evaluation the slides were stained with haematoxylin, counter-stained with eosin and examined under a light microscope (Zeiss 459300, Germany) coupled with a camera (Canon PowerShot A620, Japan) and computer. Villus length (from the tip to crypt mouth), crypt depth (from the crypt mouth to base) and width of the tunica mucosa (from the tip of the villi to the bottom of the lamina muscularis mucosae), and tunica muscularis (from the tip to the bottom of the muscular layers) were measured. Measurements of villus height and crypt depth were taken only from sections where the section plane ran vertically from the tip of the villus to the base of an adjacent crypt. Averages represent at least 3 slides with a minimum of 30 well-oriented villi; intact villi and crypts were randomly selected and measured using Axio Vision LE Rel. v 4.5 software (Zeiss, Germany).

\section{TUNEL assay}

The number of apoptotic epithelial cells was determined using a terminal deoxynucleotidyl transferase-mediated deoxyuridine triphosphate nick end labelling (TUNEL) assay in paraffin-embedded sections of the jejunum for 6 birds (replications) per 

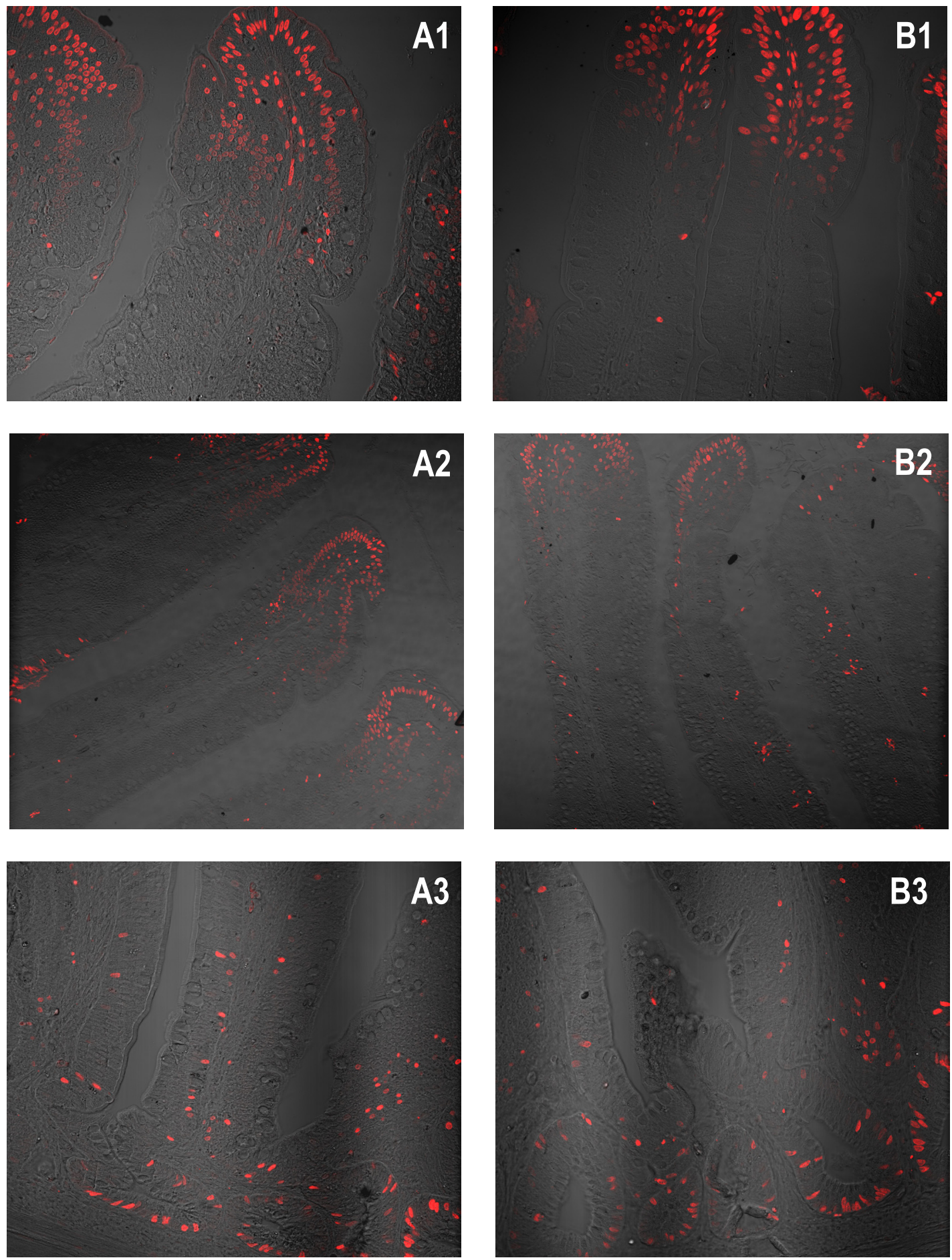

Figure 1. The apoptotic epithelial cells of jejunum of broiler chickens fed $A$ - conventional or B - MON 810 maize determined by a terminal deoxynucleotidyl transferase-mediated deoxyuridine triphosphate nick end labelling (TUNEL) assay at 400x magnification; 1 - the tip of epithelial villi; 2 - middle part of epithelial villi; 3 - crypt area

group. The antigen retrieval was performed by incubation for $15 \mathrm{~min}$ at room temperature in freshly diluted proteinase $\mathrm{K}\left(20 \mu \mathrm{g} \cdot \mathrm{ml}^{-1}\right)$ solution. The apoptosis staining procedure was performed according to the manufacturer's protocol for the assay (ApopTag, Chemicon, USA). Slides were examined under a confocal microscope (Zeiss LSM 5 Pascal, Germany) at $400 \times$ magnification. The apoptotic index was calculated separately for crypt and villi area. Six random, high-power fields for separate intact villi (200 $\mu \mathrm{m}$ from the tip of the villi) and crypts (from crypt mouth to base) were chosen and blindly quantified (Figure 1). The apoptotic index was calculated as the number of apoptotic cells among all epithelial cells of the villi and crypt area, respectively. 


\section{Immunohistochemistry}

Proliferating crypt cells were detected by immunostaining for monoclonal mouse anti-PCNA (ab29, Abcam, GB), diluted 1000-fold in 1\% BSAPBS. After $24 \mathrm{~h}$ incubation in a humidified chamber at $4^{\circ} \mathrm{C}$, the slides were washed in PBS buffer and processed according to the manufacturer's protocol for the EnVision+ system (DakoCytomation, Denmark), providing secondary goat anti-mouse $\operatorname{IgG}$ antibodies conjugated with FITC (ab7064, Abcam, GB), diluted 2000-fold in 1\% BSA-PBS. After $1 \mathrm{~h}$ incubation in a dark humidified chamber at room temperature, the slides were washed in PBS. For nuclei staining, the sections were immersed in a $1 \%$ solution of 7-AAD (Sigma-Aldrich, St. Louis MO, USA) for $25 \mathrm{~min}$ at room temperature in the dark, then washed in distilled water. Next, the slides were examined under a confocal microscope (Zeiss LSM 5 Pascal, Germany) at 40× magnification (Figure 2). PCNA-positive cells were counted and the mitotic index was calculated as the number of proliferating cells among all epithelial cells of the crypt crosssections. Control immunostaining was carried out using the same procedures, except the primary antibodies were replaced with PBS.

\section{Comet assay}

Epithelial cells from the jejunum were isolated according to a modified method of OberreutherMoschner et al. (2005) under red light to prevent additional UV-induced DNA damage. The jejunum segment was filled with $5 \mathrm{ml}$ of solution A, closed with clips and incubated for $10 \mathrm{~min}$ at $30^{\circ} \mathrm{C}$ in solution $\mathrm{A}$ in a shaking water bath. After incubation, solution A was discarded from jejunal samples since it contained mucus and debris. The jejunum segment was filled with $5 \mathrm{ml}$ of solution B (1 mM EDTA, $115 \mathrm{mM} \mathrm{NaCl}, 25 \mathrm{mM} \mathrm{NaHCO}_{3}, 2.4 \mathrm{mM} \mathrm{K}_{2} \mathrm{HPO}_{4}$, $0.4 \mathrm{mM} \mathrm{KH}_{2} \mathrm{PO}_{4}, 1 \mathrm{mM}$ dithiothreitol, $2.5 \mathrm{mM}$ L-glutamine, gassed with $95 \% \mathrm{O}_{2}-5 \% \mathrm{CO}_{2}$ ) locked with clips and incubated for $15 \mathrm{~min}$ at $30^{\circ} \mathrm{C}$ in solution B in a shaking water bath. The jejunal segments were placed on Petri dishes and gently palpated for $3 \mathrm{~min}$. The content of the jejunum segment was collected into a centrifuge tube and centrifuged for $7 \mathrm{~min}$ at $1400 \mathrm{rpm}$ at room temperature. The pellet was washed with an ice-cold solution of Dulbecco's Modified Eagle Medium (DMEM) minus phenol red, plus $1 \%$ L-glutamine and $4 \mathrm{mM} \mathrm{CaCl}_{2}$, and centrifuged again. Then the pellet was resuspended in Hank's Balanced Salt Solution (HBSS) with $0.1 \mathrm{mg} \cdot \mathrm{ml}^{-1}$ collagenase type II, incubated for $30 \mathrm{~min}$ at $30^{\circ} \mathrm{C}$, centrifuged for $7 \mathrm{~min}$ at $1400 \mathrm{rpm}$ at room temperature to remove collagenase and resuspended in DMEM. Finally, the epithelial cells were resuspended in $5 \mathrm{ml}$ of ice-cold $1 \times \mathrm{PBS}, \mathrm{pH}$ 7.4.

The comet assay was performed according to the manufacturer's instructions (Trevigen, Gaithersburg, MD, USA) using a horizontal electrophoresis tank connected with a temperature controller (Kucharczyk TE Ltd., Warsaw, Poland). The cell suspension was diluted in $1 \times \operatorname{PBS}(1: 24 \mathrm{v} / \mathrm{v})$ and combined with molten low-melting point agarose (CometAssay LMAgarose, Trevigen, Gaithersburg, MD. USA) at a ratio of 1:10 (v/v). Then, $75 \mu$ of sample was placed onto a Trevigen CometSlide ${ }^{\mathrm{TM}}$. The slides were placed at $4^{\circ} \mathrm{C}$ and left for $20 \mathrm{~min}$ to allow solidification of agarose. Afterwards, the slides were immersed in prechilled CometAssay Lysis Solution with $10 \%$ of dimethylsulfoxide and left for $40 \mathrm{~min}$ at $4^{\circ} \mathrm{C}$. After lysis, the slides were placed in a freshly prepared
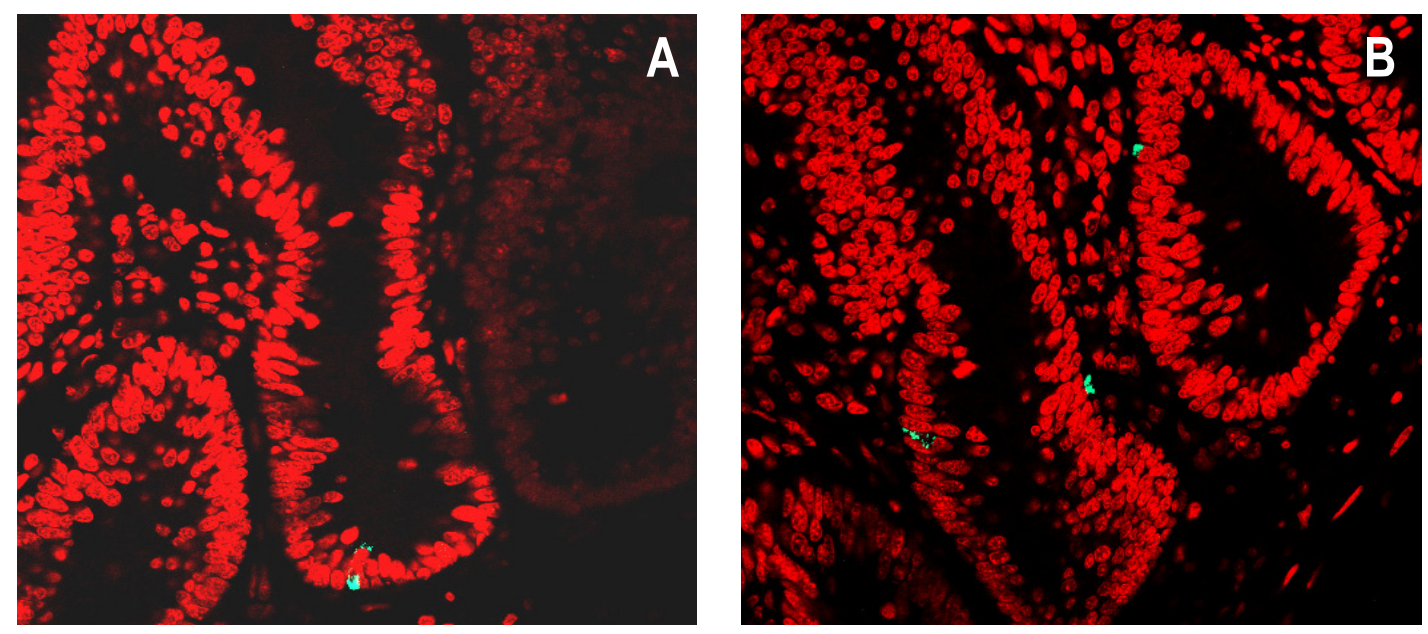

Figure 2. The mitotic epithelial cells of broiler chickens fed A - conventional or B - MON 810 maize. Determined in crypt area of jejunum by immunohistochemistry method at $40 \times$ magnification 
alkaline solution $(300 \mathrm{mM} \mathrm{NaOH}, 1 \mathrm{mM}$ EDTA, $\mathrm{pH}>13$ ) and incubated at room temperature for 40 min to allow DNA unwinding and breakage at alkali-labile sites. The slides were then transferred to a horizontal electrophoresis apparatus and DNA electrophoresis was performed for $30 \mathrm{~min}$ at $4^{\circ} \mathrm{C}, \sim 25 \mathrm{~V}$ $(1 \mathrm{~V} / \mathrm{cm})$ and $300 \mathrm{~mA}$ (constant) in a freshly prepared alkaline electrophoresis solution $(300 \mathrm{mM} \mathrm{NaOH}$, $1 \mathrm{mM}$ EDTA, $\mathrm{pH}>13$ ). Afterwards, slides were rinsed by dipping several times in ultra-pure water, dehydrated by immersing in 70\% ethanol for $5 \mathrm{~min}$ and left to air dry overnight. A sample of cells positive for a comet tail was prepared by incubation of the cell suspension with $100 \mu \mathrm{M}$ of hydrogen peroxide for $20 \mathrm{~min}$ at $4^{\circ} \mathrm{C}$ and was handled in an identical manner as described above. The whole procedure was performed under red light. Furthermore, to avoid possible position effect during electrophoresis, two parallel slides were prepared per sample. The slides were stained with $50 \mu \mathrm{l}$ of ethidium bromide $\left(2 \mu \mathrm{g} \cdot \mathrm{ml}^{-1}\right)$ for $5 \mathrm{~min}$ and next were examined at $40 \mathrm{x}$
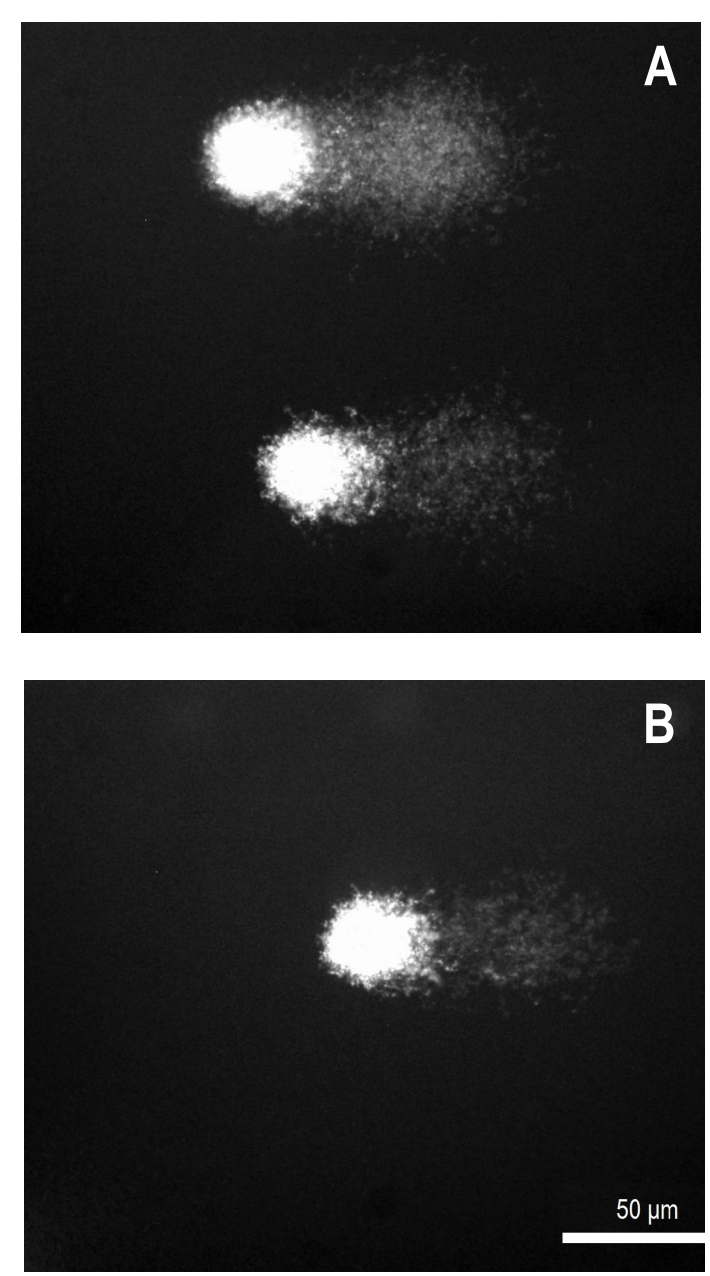

Figure 3. The degradation of DNA in mucosal cells of jejunum of broilers fed A - conventional or B - MON 810 maize, determined by a Comet assay at $40 \times$ magnification magnification under a fluorescent Olympus BX51 microscope (Olympus Corp., Tokyo, Japan), which was equipped with a 510-550 nm excitation filter and a $590 \mathrm{~nm}$ barrier filter (Figure 3). For each sample, 150 randomly selected comets were scored ( 75 from each of two replicate slides). Comet parameters were measured and DNA damage was calculated as the Tail DNA, expressed as the percentage of DNA in the comet tail relative to the total nuclear DNA by using Komet 6.0 image analysis software (Andor Technology, Belfast, UK).

\section{Calculations and statistical analysis}

Data were analysed as a $2 \times 2 \times 2$ factorial arrangement with three-way ANOVA, using the Statgraphics Plus $^{\circledR}$ ver. 5.1 software (Statgraphics, 1994-2001). When the ANOVA indicated significant treatment effects, means were separated using Duncan's multiple range tests. The results in tables are presented as mean values with pooled standard errors. Differences were considered to be significant at $P \leq 0.05$.

\section{Results}

The effects of feeding GM soyabean meal GTS 40-3-2 and two cultivars of GM MON 810 maize on the morphology of the jejunal mucosa are shown in Table 1. The use of GM SBM in diets did not affect villus length, crypt depth, tunica mucosa or tunica muscularis widths in the jejunal mucosa. Maize cultivar had no influence on any of the measured parameters, and GM maize affected neither villus length, crypt depth, nor tunica muscularis width, however, it enlarged the width of the tunica mucosa by $8.8 \%(P<0.05)$. There was also an interaction between the influence of dietary treatments on the last parameters $(P<0.05)$, as the tunica mucosa width in the group fed conventional SBM and GM maize F56 was higher, while in the group fed GM SBM and GM maize F56, was equal to that in the respective groups fed conventional F58 maize.

In comparison with the respective conventional SBM and maize, neither GM SBM, GM maize, nor maize cultivar affected villus length, crypt depth, or tunica mucosa and tunica muscularis widths in the ileal mucosa of broilers (Table 2).

The main effects of GM soyabean meal and two cultivars of GM maize on apoptosis and proliferation of the jejunal mucosal cells are shown in Table 3. In all treatment groups, apoptotic cells were present both in villi tips as well as in the crypt area of the jejunal mucosa. The use of GM soyabean meal in diets did not affect the counts of apoptotic cells in 
Table 1. Effects of feeding conventional (S) or GM (SG) soyabean meal and conventional maize (Clarica and PR39F58) or their GM counterparts (Bacilla and PR39F56) on morphology of the jejunal mucosa of broilers

\begin{tabular}{|c|c|c|c|c|}
\hline Indices & $\begin{array}{l}\text { Villus } \\
\text { length, } \mu \mathrm{m}^{1}\end{array}$ & $\begin{array}{l}\text { Crypt } \\
\text { depth, } \mu m^{1}\end{array}$ & $\begin{array}{l}\text { Tunica } \\
\text { mucosa } \\
\text { width, } \mu m^{1}\end{array}$ & $\begin{array}{l}\text { Tunica } \\
\text { muscularis } \\
\text { width, } \mu \mathrm{m}^{1}\end{array}$ \\
\hline \multicolumn{5}{|l|}{ Dietary treatment } \\
\hline SC & 866 & 119 & 963 & 125 \\
\hline SB & 877 & 124 & 975 & 126 \\
\hline SF58 & 829 & 124 & 909 & 118 \\
\hline SF56 & 933 & 149 & 1022 & 131 \\
\hline SGC & 842 & 209 & 819 & 109 \\
\hline SGB & 904 & 141 & 1019 & 135 \\
\hline SGF58 & 882 & 136 & 962 & 123 \\
\hline SGF56 & 854 & 123 & 958 & 127 \\
\hline pooled SEM & 35.0 & 32.3 & 53.3 & 10.3 \\
\hline \multicolumn{5}{|l|}{ Main effect ${ }^{2}$} \\
\hline \multicolumn{5}{|l|}{ soyabean meal (S) } \\
\hline conventional & 877 & 129 & 967 & 125 \\
\hline GM (GTS40-3-2) & 870 & 152 & 940 & 124 \\
\hline \multicolumn{5}{|l|}{ maize $(\mathrm{M})$} \\
\hline conventional & 855 & 147 & $913^{\mathrm{a}}$ & 119 \\
\hline GM (MON 810) & 892 & 134 & $993^{b}$ & 130 \\
\hline pooled SEM & 17.5 & 16.1 & 26.6 & 5.1 \\
\hline \multicolumn{5}{|l|}{ maize cv. (MC) } \\
\hline Clarica/Bacilla & 872 & 148 & 944 & 124 \\
\hline PR39 & 875 & 133 & 963 & 125 \\
\hline pooled SEM & 17.5 & 16.1 & 26.6 & 5.1 \\
\hline \multicolumn{5}{|l|}{ Interaction } \\
\hline$S \times M$ & Ns & Ns & Ns & Ns \\
\hline$S \times M C$ & Ns & Ns & Ns & Ns \\
\hline$M \times M C$ & Ns & Ns & Ns & Ns \\
\hline$S \times M \times M C$ & Ns & Ns & 0.047 & Ns \\
\hline
\end{tabular}

${ }^{1}$ means of 8 chickens, ${ }^{2}$ for main effects; $n=32$; ${ }^{a, b}$ within dietary treatments and main effects means in columns with different superscripts differ significantly at $P<0.05$; Ns - not significant

villi tips or the apoptotic and mitotic indices in the crypt area in comparison with conventional SBM. The counts of apoptotic cells in villi tips increased by $44 \%(P<0.05)$ in birds fed diets with GM compared with conventional maize, while the apoptotic and mitotic indices in crypts were not affected. The maize cultivar had no influence on the apoptotic and mitotic indices in the crypt area, or on the counts of apoptotic cells in the tips of jejunal mucosa villi. There was an interaction between the influence of GM modification and cultivar of maize on the apoptotic index in the crypt area $(P<0.05)$, as it in-
Table 2. Effects of feeding conventional (S) or GM (SG) soyabean meal and conventional maize (Clarica and PR39F58) or their GM counterparts (Bacilla and PR39F56) on morphology of the ileal mucosa of broilers

\begin{tabular}{|c|c|c|c|c|}
\hline Indices & $\begin{array}{l}\text { Villus } \\
\text { length, } \mu \mathrm{m}^{1}\end{array}$ & $\begin{array}{l}\text { Crypt } \\
\text { depth, } \mu m^{1}\end{array}$ & $\begin{array}{l}\text { Tunica } \\
\text { mucosa } \\
{ }_{1} \text { width, } \mu m^{1}\end{array}$ & $\begin{array}{l}\text { Tunica } \\
\text { muscularis } \\
{ }^{1} \text { width, } \mu \mathrm{m}^{1}\end{array}$ \\
\hline \multicolumn{5}{|l|}{ Dietary treatment } \\
\hline SC & 631 & 141 & 800 & 204 \\
\hline SB & 618 & 145 & 774 & 210 \\
\hline SF58 & 623 & 202 & 688 & 196 \\
\hline SF56 & 629 & 137 & 766 & 215 \\
\hline SGC & 638 & 125 & 765 & 202 \\
\hline SGB & 592 & 122 & 735 & 200 \\
\hline SGF58 & 667 & 134 & 812 & 222 \\
\hline SGF56 & 583 & 119 & 722 & 190 \\
\hline pooled SEM & 30.0 & 25.5 & 40.4 & 14.3 \\
\hline \multicolumn{5}{|l|}{ Main effect ${ }^{2}$} \\
\hline \multicolumn{5}{|l|}{ soyabean meal (S) } \\
\hline conventional & 625 & 156 & 757 & 206 \\
\hline GM (GTS40-3-2) & 620 & 125 & 759 & 204 \\
\hline pooled SEM & 15.0 & 12.7 & 20.2 & 7.1 \\
\hline \multicolumn{5}{|l|}{ maize $(\mathrm{M})$} \\
\hline conventional & 640 & 151 & 766 & 206 \\
\hline GM (MON 810) & 605 & 131 & 749 & 204 \\
\hline pooled SEM & 15.0 & 12.7 & 20.2 & 7.1 \\
\hline \multicolumn{5}{|l|}{ maize cv. (MC) } \\
\hline Clarica/Bacilla & 620 & 133 & 769 & 204 \\
\hline PR39 & 626 & 148 & 747 & 206 \\
\hline pooled SEM & 15.0 & 12.7 & 20.2 & 7.1 \\
\hline Interaction & & & & \\
\hline
\end{tabular}

${ }^{1}$ means of 8 chickens, ${ }^{2}$ for main effects $n=32$; all interactions insignificant

creased due to the use of GM Bacilla maize and decreased due to the use of GM F56 maize compared with their respective conventional counterparts.

The average tail DNA in experimental groups ranged from $40.1 \%$ to $51.3 \%$ of total nuclear DNA. Neither substituting conventional SBM by its GM counterpart, nor conventional maize by GM maize increased DNA damage in the epithelial cells of chicken jejunum (Table 3). Maize cultivar also had no effect in terms of DNA damage.

\section{Discussion}

In non-ruminant animals, the small intestinal mucosa plays significant role in the digestion and absorption of nutrients. Some components of ingested feed may, however, interfere with intestinal morphology and induce morphological changes in 
Table 3. Effects of feeding conventional (S) or GM (SG) soyabean meal and conventional maize (Clarica and PR39F58) or their GM counterparts (Bacilla and PR39F56) on apoptotic counts, apoptotic and mitotic indexes and tail DNA in jejunal mucosal cells

\begin{tabular}{|c|c|c|c|c|}
\hline Indices & $\begin{array}{l}\text { Apoptotic } \\
\text { counts } \\
\text { in tip of villi }{ }^{1}\end{array}$ & $\begin{array}{l}\text { Apoptotic } \\
\text { index in } \\
1 \text { crypts }^{1}, \%\end{array}$ & $\begin{array}{l}{ }_{\text {Mitotic index }} \\
\text { in crypts } 1, \%\end{array}$ & $\begin{array}{l}\text { Tail DNA }{ }^{3} \text {, } \\
\%\end{array}$ \\
\hline \multicolumn{5}{|l|}{ Dietary treatment } \\
\hline SC & 27.8 & 6.57 & 1.60 & 40.10 \\
\hline SB & 41.7 & 10.14 & 1.52 & 51.36 \\
\hline SF58 & 31.6 & 10.82 & 1.47 & 43.42 \\
\hline SF56 & 31.4 & 6.68 & 1.47 & 48.78 \\
\hline SGC & 31.2 & 7.84 & 1.51 & 50.79 \\
\hline$S G B$ & 42.7 & 9.94 & 1.35 & 45.62 \\
\hline SGF58 & 17.5 & 10.46 & 1.39 & 42.75 \\
\hline SGF56 & 40.3 & 8.66 & 1.41 & 46.42 \\
\hline pooled SEM & 7.89 & 1.787 & 0.090 & 1.278 \\
\hline \multicolumn{5}{|c|}{$\begin{array}{l}\text { Main effect }{ }^{2} \\
\text { soyabean meal (S) }\end{array}$} \\
\hline conventional & 33.1 & 8.55 & 1.51 & 45.92 \\
\hline GM (GTS 40-3-2) & 32.9 & 9.22 & 1.41 & 46.40 \\
\hline $\begin{array}{l}\text { pooled SEM } \\
\text { maize }(\mathrm{M})\end{array}$ & 3.95 & 0.893 & 0.045 & 1.782 \\
\hline conventional & $27.0^{\mathrm{a}}$ & 8.92 & 1.49 & 44.26 \\
\hline GM (MON 810) & $39.0^{\mathrm{b}}$ & 8.85 & 1.44 & 48.05 \\
\hline $\begin{array}{r}\text { pooled SEM } \\
\text { maize cv. }(\mathrm{MC})\end{array}$ & 3.95 & 0.893 & 0.045 & 1.782 \\
\hline Clarica/Bacilla & 35.8 & 9.62 & 1.49 & 46.97 \\
\hline PR39 & 30.2 & 9.15 & 1.43 & 45.34 \\
\hline pooled SEM & 3.95 & 0.893 & 0.045 & 1.782 \\
\hline \multicolumn{5}{|l|}{ Interaction } \\
\hline$S \times M$ & Ns & Ns & Ns & Ns \\
\hline$S \times M C$ & Ns & Ns & Ns & Ns \\
\hline$M \times M C$ & Ns & 0.027 & Ns & Ns \\
\hline$S \times M \times M C$ & Ns & Ns & Ns & Ns \\
\hline
\end{tabular}

${ }^{1}$ means of 6 chickens, ${ }^{2}$ for main effects $n=24 ;{ }^{3}$ percent DNA in the comet tail of mucosal cells, means of 8 chickens, for main effects $\mathrm{n}=32$; ${ }^{\mathrm{ab}}$ within dietary treatments and main effects means in columns with different superscripts differ significantly at: $P<0.05$; Ns - not significant

small intestinal walls, which can have beneficial or detrimental consequences for gut health and feed conversion ratio. Generally, shortening of the villi decreases the surface area for nutrient absorption, while increased crypt depth points to faster cell turnover and can be accompanied by increased water secretion into the intestinal lumen (Montagne et al., 2003). Villous height, crypt depth, and villous height/crypt depth ratio may be used as indicators of intestinal health (Zhang et al., 2014).

In the present study, villous height and crypt depth did not differ in either the jejunum or ileum of broilers fed GM soyabean meal and/or GM maize in comparison with the respective conventional feeds. Only the width of the jejunal tunica mucosa was greater in birds fed GM maize compared with birds fed the respective conventional maize. It seems that GM feeds did not interfere with small intestinal functional structure. This agrees with data concerning the nutritional equivalence of GTS-40-3-2 soyabean meal and MON 810 maize and their non-transgenic counterparts (Czerwiński et al., 2015). Similar findings were reported in the literature. Reichert et al. (2012) did not find significant differences in the morphology of the duodenum and jejunum in broiler chickens, laying hens, fattening pigs, and calves fed MON 810 maize and GTS-40-3-2 (Roundup Ready) soyabean meal or their respective non-transgenic counterparts. Kiliç and Akay (2008) in a threegeneration study on rats found no differences in the morphology of the duodenum between animals fed diets containing GM Bt maize or its conventional counterpart. Walsh et al. (2012) showed that feeding male weanling pigs for 31 days with MON 810 maize had no influence on villus heights, crypt depths, or villus height-to-crypt depth ratios in the duodenum, jejunum, and ileum. Buzoianu et al. (2012) found no adverse effect of long-term feeding of pigs with MON 810 maize on the morphometry of the small intestine. Nonetheless, in a study on sows during gestation and lactation and on their offspring from weaning to $115 \mathrm{~d}$ post weaning, although the use of GM maize did not affect the morphometric indices in the jejunum and ileum of sows, the offspring from sows fed the Bt maize diets had deeper crypts and a lower villus height/crypt depth ratios in the duodenum than offspring from sows fed the isogenic non-GM maize diets (Buzoianu et al. 2013).

Functional development and maturation of the gastrointestinal tract is essential for the health and successful production of poultry and other domestic animals. The morphological and functional development of the small intestine after hatching in meattype birds is rapid, with differing rates of enterocyte proliferation, migration, and turnover. Proliferating cells are located mainly in the crypt area and up to the middle area of the villus (Uni, 1999). A dietary challenge, such as chronic aflatoxin $\mathrm{B}_{1}$ exposure, can reduce cellular proliferation in the jejunal tissues of broilers (Zhang et al., 2014). In the current study, the percent of proliferating cells (mitotic index) in the crypt area of the jejunum was similar in birds fed diets containing GM soyabean meal and/or GM maize and their conventional counterparts. This points to the nutritional equivalence of GM and conventional feeds.

Apoptosis (programmed cell death) is a normal part of tissue development and maintenance. Apoptosis in the intestinal crypts of the gut regulates the total amount of progenitor stem cells, while in the vil- 
lous tips of epithelial cells it influences desquamation and exfoliation (Potten, 1997). Apoptosis under various pathological conditions may help eliminate damaged or infected cells (Major et al., 2011) and may also occur as a response to various environmental stimuli, indicating toxicity. Peng et al. (2014) found a higher number of apoptotic cells in the jejunum of broilers fed a diet contaminated with aflatoxin $\mathrm{B}_{1}\left(0.3 \mathrm{mg} \cdot \mathrm{kg}^{-1}\right.$ diet $)$. In the current study, the counts of apoptotic cells in the tips of jejunal villi of broilers fed diets with GM SBM were comparable to those in birds fed the conventional SBM, but in birds fed with GM maize, they were higher than in birds fed conventional maize. However, the apoptotic index in the crypt area was higher only in birds fed GM Bacilla maize compared with the conventional Clarica counterpart, while it was lower in birds fed GM F56 maize than conventional F58 maize. These results cannot be connected with aflatoxin contamination as it was low and uniform in all of the maize samples used, but involvement of other mycotoxins cannot be excluded. Both GM maize cv. Bacilla and cv. F56 had higher contents of deoxynivalenol (DON) than their conventional counterparts (296 and 217 vs $56 \mu \mathrm{g} \cdot \mathrm{kg}^{-1}$, respectively), cv. Bacilla also had a higher content of zearalenone ( $29 \mathrm{vs} 2.6 \mu \mathrm{g} \cdot \mathrm{kg}^{-1}$, respectively) (Czerwiński et al., 2015).

Feed contaminants may be involved in cell injury, DNA damage and apoptosis. Awad et al. (2014) showed a genotoxic effect of deoxynivalenol (DON) in the form of lymphocyte DNA damage in broilers. However, in the current study, neither GM SBM nor GM MON 810 maize exhibited DNAdamaging effects in the intestinal epithelial cells of broiler chickens.

\section{Conclusions}

In conclusion, the presented results show that the functional development and maturation of the small intestinal epithelium is not greatly affected by the use of genetically modified Roundup Ready soyabean meal (GTS 40-3-2) and/or genetically modified maize (MON 810) in broiler diets.

\section{Acknowledgements}

Financial support was provided by the Polish National Science Centre - Grant No. N N311 517540.

\section{References}

Awad W.A., Ghareeb K., Dadak A., Hess M., Böhm J., 2014. Single and combined effects of deoxynivalenol mycotoxin and a microbial feed additive on lymphocyte DNA damage and oxidative stress in broiler chickens. PLoS ONE 9 (1): e88028, www. plosone.org

Buzoianu S.G., Walsh M.C., Rea M.C., Cassidy J.P., Ross R.P., Gardiner G.E., Lawlor P.G., 2012. Effect of feeding genetically modified Bt MON810 maize to 40-day-old pigs for 110 days on growth and health indicators. Animal 6, 1609-1619

Buzoianu S.G., Walsh M.C., Rea M.C., Cassidy J.P., Ryan T.P., Ross R.P., Gardiner G.E., Lawlor P.G., 2013. Transgenerational effects of feeding genetically modified maize to nulliparous sows and offspring on offspring growth and health. J. Anim. Sci. 91, 318-330

Chłopecka M., Mendel M., Dziekan N., Karlik W., 2014. Glyphosate affects the spontaneous motoric activity of intestine at very low doses - in vitro study. Pestic. Biochem. Physiol. 113, 25-30

Clair E., Mesnage R., Travert C., Séralini G.E., 2012. A glyphosatebased herbicide induces necrosis and apoptosis in mature rat testicular cells in vitro, and testosterone decrease at lower levels. Toxicol. Vitro 26, 269-279

Czerwiński J., Bogacki M., Jalali B.M., Konieczka P., Smulikowska S., 2015. The use of genetically modified Roundup Ready soyabean meal and genetically modified MON 810 maize in broiler chicken diets. Part 1. Effects on performance and blood lymphocyte subpopulations. J. Anim. Feed Sci. 24, 134-143

EFSA, 2011. Guidance for risk assessment of food and feed from genetically modified plants. EFSA Panel on Genetically Modified Organisms (GMO). EFSA J. 9, 2150

Einspanier R., 2013. The fate of transgenic DNA and newly expressed proteins. In: G. Flachowsky (Editor). Animal Nutrition with Transgenic Plants. CABI Biotechnology Series, pp. 130-139

Flachowsky G., 2013. Feeding studies with first-generation GM plants (input traits) with food-producing animals. In: G. Flachowsky (Editor). Animal Nutrition with Transgenic Plants. CABI Biotechnology Series, pp. 72-93

Heu C., Berquand A., Elie-Caille C., Nicod L., 2012a. Glyphosateinduced stiffening of HaCaT keratinocytes, a Peak Force Tapping study on living cells. J. Struct. Biol. 178, 1-7

Heu C., Elie-Caille C., Mougey V., Launay S., Nicod L., 2012b. A step further toward glyphosate-induced epidermal cell death: involvement of mitochondrial and oxidative mechanisms. Environ. Toxicol. Pharmacol. 34, 144-153

ISAAA, 2014. Global status of commercialized biotech/GM crops: 2014. International Service for the Acquisition of Agri-biotech Applications in Brief, No. 49-2014. ISAAA: Ithaca, NY. http:// www.isaaa.org/resources/publications/briefs/49/executivesummaryl

Kiliç A., Akay M.T., 2008. A three generation study with genetically modified Bt corn in rats: Biochemical and histopathological investigation. Food Chem. Toxicol. 46, 1164-1170

Major P., Toth S., Goldova M., et al., 2011. Dynamic of apoptosis of cells in duodenal villi infected with Eimeria acervulina in broiler chickens. Biologia 66, 696-700

Montagne L., Pluske J.R., Hampson D.J., 2003. A review of interactions between dietary fibre and the intestinal mucosa, and their consequences on digestive health in young non-ruminant animals. Anim. Feed Sci. Tech. 108, 95-117

NRC, 1994. Nutrients Requirements of Poultry. $9^{\text {th }}$ Edition. National Academy Press. Washington, DC 
Oberreuther-Moschner D.L., Rechkemmer G., Pool-Zobel B.L., 2005. Basal colon crypt cells are more sensitive than surface cells toward hydrogen peroxide, a factor of oxidative stress. Toxicol. Lett. 159, 212-218

Peng X., Zhang S., Fang J., Cui H., Zuo Z., Deng J., 2014. Protective roles of sodium selenite against aflatoxin $B_{1}$ - induced apoptosis of jejunum in broilers. Int. J. Environ. Res. Public Health $11,13130-13143$

Potten C.S., 1997. Epithelial cell growth and differentiation. II. Intestinal apoptosis. Amer. J. Physiol. 27, 253-257

Reichert M., Kozaczyński W., Karpińska T.A. et al., 2012. Histopathology of internal organs of farm animals fed genetically modified corn and soyabean meal. Bull. Vet. Inst. Puławy 56, 617-622

Świątkiewicz S., Twardowska M., Markowski J., Mazur M., Sieradzki Z., Kwiatek K., 2010. Fate of transgenic DNA from BT corn and Roundup Ready soyabean meal in broilers fed GMO feed. Bull. Vet. Inst. Puławy 54, 237-242
Statgraphics $₫$ ver. 5.1. (1994-2001) Statistical Graphic System by Statistical Graphic Corp.

Uni Z., 1999. Functional development of the small intestine in domestic birds: Cellular and molecular aspects. Poultry Avian Biol. Rev. 10, 167-179

Walsh M.C., Buzoianu S.G., Gardiner G.E., Rea M.C, Ross R.P., Cassidy J.P., Lawlor P.G., 2012. Effects of short-term feeding of Bt MON810 maize on growth performance, organ morphology and function in pigs. Brit. J. Nutr. 107, 364-371

Zhang S., Peng X., Fang J., Cui H., Zuo Z., Chen Z., 2014. Effect of aflatoxin $B_{1}$ exposure and sodium selenite supplementation on the histology, cell proliferation, and cell cycle of jejunum in jejunum in broilers. Biol. Tr. Elem. Res. 160, 32-40 